\title{
Parameters for Achieving Innovative Maturity of the Region in the Context of Digital Transformation
}

\author{
Natalya Kazarenkova \\ Department of Finance and Credit \\ SouthWest State University \\ Kursk, Russia \\ nfedorovich@yandex.ru \\ Tatyana Kolmykova \\ Department of Finance and Credit \\ SouthWest State University \\ Kursk, Russia \\ t_kolmykova@mail.ru
}

\author{
Anna Obukhova \\ Department of Finance and Credit \\ SouthWest State University \\ Kursk, Russia \\ obuhova_anna@inbox.ru
}

\begin{abstract}
The article is devoted to the study of an urgent problem in modern realities of economic development: the study of factors that influence the economic security of the banking sector in the region. The subject of the research is the economic security of banks and the region and the factors that influence them. The article identifies the main trends in the development of the banking sector in the Belgorod Region, the main of which are: a negative trend towards a reduction in the total assets of the bank, associated with a decrease in liabilities as a result of a reduction in the main item of attracted funds from banks, customer funds (including deposits of the population); an increase in financial results by the end of the period, which indicates the effective operation of banks in the Belgorod region; increase in lending volumes while maintaining the share of overdue debt in the loan portfolio at an acceptable level. This article examines the factors that influence the economic security of the functioning of the banking sector in the region. It was revealed that the greatest impact on economic security is exerted by the quality of bank management (internal factor), as well as the influence of global risks (external factor).
\end{abstract}

Keywords-economic security, bank, region, research of factors, banking risks, banking management.

\section{INTRODUCTION}

Achieving economic growth is the most important task of any national economy. At the same time, the rapid industrial development of the world economy, as well as the fourth industrial revolution (Industry 4.0), form the prerequisites for abandoning extensive development paths in favor of improving the technological efficiency of production and the use of digital innovations in all areas of economic activity. In this regard, economic development in modern conditions is characterized by the dynamism, speed and intensity that are ensured by the digital transformation of the economic space.

First of all, this process affects the financial sector and the educational environment, which are one of the most sensitive areas for the development of digital technologies and innovations. The synergistic effect of realizing the potential of all institutions of the innovative environment of the region allows us to form the prerequisites for sustainable economic development. As a result, the use of digital ecosystems becomes one of the conditions for the formation of innovative maturity of the region, as the most important factor in the realization of the concept of post-industrial development.

The relevance of the development of the theory of innovative processes is connected with the need to assess the mechanism of influence of the digital transformation of the economy on the innovative potential of the region. The value of the study lies in justifying the scientific hypothesis about the feasibility and effectiveness of using the digital ecosystem as a stimulator for the formation of innovative maturity in the region. Summarizing the results of scientific research and experience in the implementation of regional and global digital ecosystems allows us to form an author's position on the impact of the digital transformation process on the formation of innovative maturity of the region.

It should be noted that it is especially important to achieve the regional economy's innovation maturity evenly, which will minimize asymmetry in the development of regions. However, at present, the influence of regional differentiation factors is predominant and negatively affects the level of innovative development of individual regions. A significant challenge to achieving the innovation maturity of the regional economy is to exacerbate the imbalances in socio-economic development related to the geographical, climatic and national characteristics of the region. As a result, developed regions can invest in an innovative environment, while lagging regions do not have sufficient financial resources, which only reinforces the existing imbalances in their socio-economic development. The solution to these problems can be to combine the efforts of the state, business and the scientific and educational environment into a single ecosystem, the digital transformation of which will give an impetus to the innovative development of the region and create the prerequisites for achieving the necessary level of innovation maturity. 


\section{METHODS}

The study is based on the use of the principle of objectivity (the study of the synergistic effect of the interaction of the main elements of the innovative system of the region is based on facts and real empirical results) and the principle of systematics (the object and subject of the study is considered in the relationship of all elements).

Classical methods of system analysis were used as tools in the system study of innovative potential, depending on the features of the analyzed system; special research methods: monographic, abstract-logical, methods of economicmathematical modeling and statistical research; hierarchy analysis method, planning and forecasting methods.

The research is based on the principle of the dialectical relationship of economic phenomena in the categories of cause and effect.

The research was carried out using methods of cognition of the essence of the studied subject and its object specificity, analysis of the degree of scientific development of the problem, classification and identification of its criterial foundations, construction of logical inferences, comparative analysis.

\section{MAIN PART}

Scientific research in the field of developing the innovative potential of the region is based on the provisions of the theory of innovation and develops it in relation to the process of digital transformation. The rationale for the region's innovation maturity should be based on the synthesis of scientific research within the framework of the theory of innovative development in conjunction with the model of the digital economy, the transition to which is inevitable after the end of the Fourth Industrial Revolution.

First of all, the basic concept of the theory of innovation is the identification of innovations, the consensus on the essence and content of which has not been formed. The founder of the theory of innovative development is J. Schumpeter, who defines innovation as changes caused by "new or improved solutions of a technical, technological or organizational nature in the process of production and marketing of products" [1]. P. Drucker adheres to this interpretation, according to which innovation is a "tool for implementing a new type of business or services" [2]. The group of researchers considering innovation as a change also includes L.S. Blyakhman [3], F. Nixon [4] and A.I. Prigozhin [5].

Such scientists as B. Santo [6], I. V. Safronov [7] consider innovation as a process of creating and disseminating a qualitatively new property of goods or services, a new technology or a form of organization of production. Innovation as a result prevails in the interpretations of Russian economists, first of all, scientists such as

R.A. Fathutdinov [8], Surin A.V., Molchanova O.P. [9], which is associated with the legislative consolidation of this interpretation and its use in the activities of the Agency for Innovation and the Development of Economic and Social Projects.

At the same time, J. Schumpeter offers a rather intensive classification of types of innovations, highlighting the following areas of creating innovations: the creation of new products, the development of new markets, the discovery of new sources of raw materials, the use of new technologies and equipment, a new industrial organization [1]. The above innovation structure allows you to define the parameters for achieving innovation maturity and set the directions for building the innovative potential of the region.

A large number of works of both domestic and foreign authors are currently devoted to the development of business processes in the conditions of digitalization of the economy. The basic aspects of the functioning of the digital economy are affected in the works of the Sretensky club named after S.P. Kurdyumova: V.Yu. Katasonova, V.V. Maslennikova, V.V. Ivanova [10] and were developed in the studies of M.A. Averyanov,

S.N. Yevtushenko, E.Yu. Kochetova [11], as well as V.V. Ivanova and G.G. Malinetsky [12].

The assessment of the results of using financial technologies as a tool to stimulate the development of the innovation system can be seen in the works of T.V. Polteva, N.N. Bykova [13], I.L. Avdeeva, T.A. Golovina, L.V. Parakhina [14]. Among foreign scientists who consider the fundamentals of digitalization of the economy in their works are D. Tapscott [15] and K. Schwab [16].

The process of formation of the country's innovative system, including in the regional context, is studied in the works of P. Lindholm, S. Klesova [17], Jensen M.B., Johnson B., Lorenz E., Lundvall B.A. [18], S.V. Basova, I.B. Ilyukhin [19]. The completeness of the implementation of innovative potential directly depends on the degree of innovation maturity of the region, the methodological basis of the assessment of which is practically not studied in modern conditions, and its individual elements are reflected in the works A.A. Adzhieva [20], D.A. Nikolaev [21], Ferhat Demir [22], J. Nick, P. Atkin [23].

The author's contribution to the development of the theory of innovative development is the substantiation of the effect of synergy between the production and financial sectors of the economy, as well as the educational environment on the formation of a mature innovation system in the region. In the context of digital transformation, it is possible to achieve the innovation maturity of the region by studying the impact of financial technologies on improving the quality, safety and effectiveness of interaction between the financial and real sectors of the regional economy, as the institutional basis of the innovation spiral. The proposed mechanism for the introduction of basic digital ecosystem tools will create the innovative potential of the region and use it to achieve its innovative maturity. The applied significance of the results is confirmed both by the development of fundamental theoretical and methodological provisions in the field of digitalization of the economy and the possibility of their use in strategic planning of the process of formation of a mature innovative environment in the region.

According to the concept of innovative development, the innovative maturity of the region is one of the decisive factors in achieving economic growth in modern conditions. The parameters of achieving innovation maturity are many functional and organizational-economic ties between the subjects of the regional economy, which form the innovative potential of the region. The link between these categories is the innovative environment of the region, which determines the external economic factors of the implementation of 
innovative potential. In turn, the internal factors of economic actors influence the innovative position and innovative activity of the regional economy in aggregate.

The maturity of the innovative environment of the regional economy, on the one hand, is the result of the realization of innovative potential, and on the other hand, forms the prerequisites for its growth. At the national level, the level of innovation maturity of the economy is characterized by a global innovation index, which is calculated as the average of subindexes of incoming and outgoing innovation flows. The incoming innovation index assesses the resource potential of the country's innovative development based on the state of the scientific and educational environment, the level of qualification of human capital, the development of the infrastructure of the innovative environment and the market environment. The emerging innovation market reflects the effectiveness of innovation based on the development of technologies, the level of digital innovation in the activities of economic entities, and the results of creative activities [24].

The innovation efficiency ratio is defined as the ratio of two subindexes, thus reflecting the aggregated innovation performance at a given innovation potential. It should be noted that the global innovation index of Russia since 2015 has been fluctuating slightly and in 2020 the country is in 47 th place in the ranking (Fig. 1).

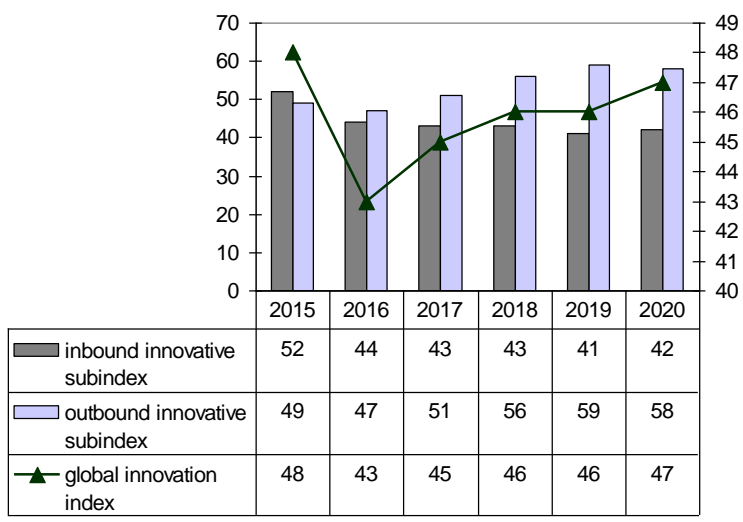

Fig. 1. Dynamics of Russia's position in the global innovation index

At the same time, traditionally, Russia's position on the incoming innovative subindex is higher than that on the outgoing subindex. This situation is due to the fact that the innovative potential of the Russian economy is not used efficiently, which leads to a gap between the amount of used resources of the innovative environment and the actual result of innovation. As a result, in the ranking of the global innovation index, Russia occupies 42 positions on innovative resources and only 58 positions on the results of innovation.

This imbalance is caused by the objective advantages and disadvantages of Russia's innovation system. Among the advantages of the Russian innovation system are:

- human capital and science (30th place in the ranking);

availability and accessibility of higher education (17th place in the ranking), including the number of graduates of engineering and natural sciences (15th place in the ranking);

- level of market development, first of all, the scale of the domestic market (6th place in the ranking);
- level of business development in terms of employment in knowledge-intensive industries (18th place in the ranking) and cash flows related to intellectual property (17th place in the ranking);

- development of advanced technologies and knowledge economy, including the number of patents for inventions (17th place in the ranking) and useful models (5th place in the ranking).

At the same time, it is necessary to note the obstacles and negative factors of the innovative development of the Russian economy:

- Regulatory and legal regulation of innovation activity (105th place in the ranking);

- development of innovative infrastructure, first of all, environmental sustainability (101 place in the ranking) and energy efficiency (115 place in the ranking);

- the level of development of the investment market in general (106th place in the ranking) and microfinance in particular (77th place in the ranking);

- level of business participation in the scientific and educational environment (91st place in the ranking);

- results of creative activity in the field of feature films (81 places in the ranking) and the media (76 place in the ranking).

The global innovation index of Russia is influenced by the degree of development of the innovation environment of the regions, which confirms the importance of achieving innovation maturity in each region. Currently, the territorial distribution of regions according to the criterion of maturity of the innovative environment and the development of innovative potential reflects the weakness of the socioeconomic infrastructure of the regional economy. As a result, the share of regions among strong innovators at the end of 2019 year amounted to only $13.2 \%$, and the combined share of medium and weak innovators among Russian regions reaches $55.5 \%$ (Fig. 2).

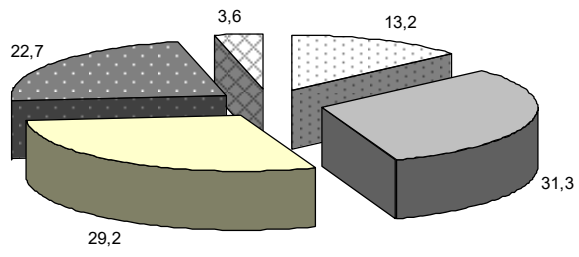

$\square$ strong innovators $\square$ medium-strong innovators $\square$ medium-sized innovators

$\square$ medium-weak innovators $\square$ weak innovators

Fig. 2. Rating of Russian regions by the degree of innovative development

Differentiation of regions by the maturity of the innovative environment, the degree of implementation of innovative potential and clustering by the main parameters of innovative development allows us to make the Russian Regional Innovation Index (RRII). Structurally, the regional innovation index allows assessing the following parameters of the region's innovative development: socio-economic conditions 
of innovation (ISEC), scientific and technical potential (ISTP), innovation (II), export activity (IEA) and quality of innovation policy (IQIP). In the regional structure of the Russian economy there is no clear leader who has the maximum possible characteristics of the development of innovation. However, according to the totality of the influence of individual parameters of innovative potential, four clusters can be distinguished, reflecting the steady unevenness of the innovative development of the regional economy:

- leading regions include the leader of the innovative development rating and regions whose RRII value deviates by no more than $20 \%$ from the maximum value; Moscow, Tatarstan and St. Petersburg steadily occupy leading positions in the ranking, the remaining regions belong to the Central, Volga and Siberian federal districts;

- regions catching up with the leader are inferior in value to the RII from $20 \%$ to $40 \%$ and make up the largest group, including 42 regions mainly from the Volga and Central federal districts;

regions with an average level of innovative development lag behind the leader from $40 \%$ to $60 \%$, consist of 29 regional entities and are more evenly distributed throughout the country;

- regions with a low level of innovative development lag behind the leader by more than $60 \%$, such subjects prevail in the North Caucasus and Far Eastern federal districts.

It should be noted that even in the lead regions, the distribution of parameters of innovation maturity is uneven. So, the leader of the national rating - Moscow - has an advantage only in the socio-economic conditions of innovative development, while Tatarstan is the leader in innovation activity and quality of innovation policy, St. Petersburg is the leader in export activity, and Tomsk Region is the leader in scientific and technical potential. The distribution of the most innovative regions of Russia in the main areas of formation of innovative potential is clearly shown in Table 1 .

TABLE I. RANKING OF LEADING REGIONS BY VALUE OF REGIONAL INNOVATION INDEX BY THEMATIC SUB-INDICES

\begin{tabular}{|l|c|c|c|c|c|}
\hline Region & ISEC & ISTP & II & IEA & IQIP \\
\hline Moscow & 1 & 5 & 7 & 2 & 2 \\
\hline $\begin{array}{l}\text { Republic of } \\
\text { Tatarstan }\end{array}$ & 2 & 13 & 1 & 9 & 1 \\
\hline $\begin{array}{l}\text { St. } \\
\text { Petersburg }\end{array}$ & 3 & 3 & 3 & 1 & 9 \\
\hline $\begin{array}{l}\text { Tomsk } \\
\text { region }\end{array}$ & 4 & 1 & 4 & 18 & 4 \\
\hline $\begin{array}{l}\text { Nizhny } \\
\text { Novgorod } \\
\text { Region }\end{array}$ & 34 & 4 & 8 & 3 & 6 \\
\hline $\begin{array}{l}\text { Moscow } \\
\text { region }\end{array}$ & 32 & 6 & 12 & 13 & 7 \\
\hline $\begin{array}{l}\text { Sverdlovsk } \\
\text { region }\end{array}$ & 7 & 10 & 17 & 20 & 11 \\
\hline $\begin{array}{l}\text { Novosibirsk } \\
\text { region }\end{array}$ & 38 & 8 & 37 & 7 & 3 \\
\hline
\end{tabular}

Despite the leading positions, the regions have problems in certain areas of innovation. A significant deviation from leadership can be noted according to the socio-economic conditions of innovative development in the Moscow region (32nd place in the ranking), the Nizhny Novgorod region (34th place in the ranking) and the Novosibirsk region (38th place in the ranking). In the Novosibirsk region, there are also problems with innovation, in particular with activity in the field of innovation of both technological and nontechnological nature, with costs of technological innovation and efficiency of innovation - according to the innovation index, the region occupies only 37 th place in the ranking.

In general, the level of innovative activity of Russian organizations has been declining since 2017, despite a significant increase in both investments in innovative activities and results from the implementation of innovative goods, works and services (Fig. 3).

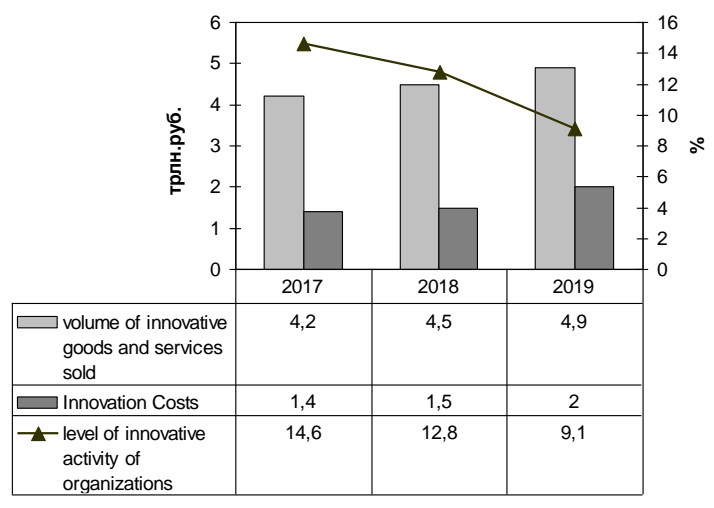

Fig. 3. Characteristics of innovation activity of Russian organizations

Despite the general trend of declining innovative activity of Russian organizations, it is possible to distinguish territorial associations with a share of innovative organizations, higher than the national average in 2019:

- The Central Federal District has innovative activity at the level of $10.8 \%$ (18.5\% according to the results of 2017), the leader is the Belgorod Region with an indicator of $15.1 \%$, outsiders are the Kostroma Region and the Kursk Region with an indicator of $4.6 \%$ and $5.4 \%$, respectively;

- The North-West Federal District, the level of innovative activity of which is $10.1 \%$ (15.9\% according to the results of 2017), leads St. Petersburg and the Vologda Oblast with an indicator of $15.4 \%$ and $11.6 \%$, respectively, and the Nenets Autonomous Okrug with an indicator of $2.7 \%$;

- Volga Federal District with an innovative activity level of $11.6 \%$ (14.3\% according to the results of 2017), led by the Republic of Mordovia and the Republic of Tatarstan with an indicator of $21.2 \%$ and $17.4 \%$, respectively, and the outsider is the Orenburg region with an indicator of 5.6\%;

- The Ural Federal District slightly exceeds the average level of innovative activity, its indicator is $9.3 \%(15.7 \%$ according to the results of 2017), there are no clear leaders, the Sverdlovsk Region is the most active with an indicator of $11.6 \%$.

The level of innovative activity is differentiated not only by territory, but also by types of economic activity. As a rule, knowledge-intensive areas of activity have innovative activity, among which, according to the results of 2019, we can distinguish: manufacturing with an indicator of $20.5 \%$ (the highest level is observed in the production of petroleum products $-27.5 \%$, chemical production $-26 \%$, metallurgy - 
$29 \%$, computer and electronic production $-49.8 \%$, motor vehicle production $-36.6 \%$ ), telecommunications activities with an indicator of $12.6 \%$, as well as scientific research and development with an indicator of $51.3 \%$. These areas can be considered the growth points of the innovative potential of the region, considered the growth points of the innovative potential of the region, the presence and development of which will contribute to the formation of innovation maturity.

At the same time, a significant share of knowledgeintensive areas of activity in Russia has an insufficient, and often low, level of innovative activity. First of all, agriculture should be noted with an average of $3.9 \%$ in the industry, mining $-6.8 \%$, construction $-3.6 \%$, information technology activities - 5.5\%, health and social services - 5.3\%. The elimination of the identified bottlenecks will expand the opportunities for innovative development, both in individual regions and in the national economy as a whole.

Thus, the formation of innovative maturity of the regions of Russia in the context of digital transformation should be based on the existing innovative potential, taking into account the possibilities of its expansion, as well as take into account the current innovative position of regional organizations and the directions of their innovation activities. The tool for solving this problem is the digital ecosystem, as a result of the innovative interaction of regional economic entities, regional authorities and the scientific and educational environment [25]. The use of digital ecosystems to achieve innovative maturity in the region involves the following areas of digitalization:

1. Digitalization of the population involves the active use of digital services by increasing the availability of the Internet throughout the country, including the following goals and directions:

- Search for information on goods and services;

- Telephone and video calls over the Internet;

- Participation in social networks;

- e-mail communication;

- financial transactions and transactions in remote format.

2. The digitalization of organizations involves at least the presence of its own website and the use of electronic document management, as well as the digitalization of workplaces with the possibility of using remote access to work functions, the use of special software and information technologies in the activities of organizations.

3. Digitalization of the state involves the development and implementation of digital services within a single digital space, the possibility of obtaining public services in $24 / 7$ mode through the integration of the State Services digital platform with the interagency electronic interaction system, and improving the quality of public administration based on the Smart Region system.

Implementation of the digital ecosystem in the region is possible subject to certain conditions that determine the minimum level of innovative maturity. The conditions for digitalization of the regional economy include: the presence and state of digital infrastructure, the development of digital competencies of the population, the degree of digitalization of education, the spatial structure, the development of science and innovation, financial and material resources.
The digitalization process contributes to the transformation of the world economy and a shift in emphasis from the production sector to the financial and technological sector. Over the past ten years, the ranking of the largest capitalization companies has undergone significant changes: the share of companies engaged in technology and consumer services has increased from $16 \%$ to $56 \%$, the share of financial companies - from $18 \%$ to $27 \%$, respectively. As a result, digital ecosystems predominate among the world's largest companies [26].

The transformational impact of the digital economy is becoming more obvious given the increase in the number of large technology companies - seven of the twelve largest companies by market capitalization in 2019 - Alibaba, Alphabet (Google), Amazon, Apple, Facebook, Microsoft and Tencent - are digital ecosystems. It should be noted that geographically, the concentration of digital ecosystems is associated with the United States of America and China, accounting for $90 \%$ of the market capitalization value of the world's 70 largest digital technology companies. At the same time, Google accounts for $90 \%$ of Internet search, Facebook is the main platform for social networks, Amazon accounts for $37 \%$ of Internet trade, and Amazon Web Services provide a similar share in the global cloud infrastructure services market.

As a result, digital ecosystems set the vector for modern economic development and become a link in the interaction of business, the state and end-users of goods and services. Structural shifts in the world economy and digitalization trends can no longer be ignored in economic development programmes, both at the national and regional levels. State participation in the digitalization process should not be limited only to control functions, it is necessary to integrate into digital ecosystems, which ensure effective and mutually beneficial cooperation not only of customers, partners, related industries, but also of competitors.

The key parameters of changes in the innovative environment of the region related to the use of digital ecosystems are reflected in Table 2.

Thus, through the development and implementation of digital ecosystems, the regional economy provides access to global value chains, specific services, adapts new technologies, and creates new business models. At the same time, digital ecosystems provide important development parameters for the region's innovation maturity: territorial differentiation of participants, intersectoral focus, organizational flexibility, and the continuous creation of innovative development tools and mechanisms.

\section{CONCLUSION}

The study reflected the need to form a mature innovation environment as a key factor in the development of the regional economy. A significant obstacle to this is the territorial disunity and differentiation of the innovative potential of the regions. Under these conditions, a digital ecosystem that combines the interests of all stakeholders is an effective tool for innovative development of the regional economy. 
TableII THE KEY PARAMETERS OF CHANGES IN THE INNOVATIVE ENVIRONMENT OF THE REGION

\begin{tabular}{|c|c|c|}
\hline $\begin{array}{c}\text { BUSINESS } \\
\text { MODEL } \\
\text { PARAMETER }\end{array}$ & $\begin{array}{c}\text { TRADITIONAL } \\
\text { BUSINESS MODEL }\end{array}$ & $\begin{array}{c}\text { DIGITAL BUSINESS } \\
\text { MODEL }\end{array}$ \\
\hline PURPOSE & $\begin{array}{lr}\text { PRODUCTION } & \text { OF } \\
\text { GOODS } & \text { AND } \\
\text { PROVISION } & \text { OF } \\
\text { SERVICES } & \end{array}$ & $\begin{array}{lr}\text { INTEGRATIVE } & \text { SMART } \\
\text { SOLUTIONS, INNOVATIVE } \\
\text { PRODUCTS } \\
\text { TECHNOLOGIES, SPEED TO } \\
\text { MARKET, AND MARKET } \\
\text { LEADERSHIP }\end{array}$ \\
\hline STRUCTURE & RIGID STRUCTURE & $\begin{array}{l}\text { FLEXIBLE STRUCTURE WITH } \\
\text { HIGH DEGREE OF } \\
\text { ADAPTATION TO EXTERNAL } \\
\text { CONDITIONS }\end{array}$ \\
\hline SUBJECTS & $\begin{array}{l}\text { MATURE MARKET } \\
\text { PARTICIPANTS } \\
\text { DOMINATE, A } \\
\text { CLEAR DISTINCTION } \\
\text { BETWEEN BUYERS, } \\
\text { SUPPLIERS, } \\
\text { PARTICIPANTS AND } \\
\text { COMPETITORS }\end{array}$ & $\begin{array}{l}\text { MARKET DEVELOPMENT BY } \\
\text { NEW PARTICIPANTS, } \\
\text { CONGLOMERATION } \\
\text { CONSUMERS, } \\
\text { MANUFACTURERS, } \\
\text { COMPETITORS }\end{array}$ \\
\hline FOCUS & $\begin{array}{l}\text { INTRA-INDUSTRY } \\
\text { FOCUS WITH FOCUS } \\
\text { ON PRODUCTION } \\
\text { ASSETS }\end{array}$ & $\begin{array}{lr}\text { CROSS-INDUSTRY } & \text { FOCUS } \\
\text { FOCUSED ON } & \text { BUSINESS } \\
\text { INNOVATION } & \text { AND } \\
\text { INTELLECTUAL PROPERTY }\end{array}$ \\
\hline $\begin{array}{lr}\text { TYPE } & \text { OF } \\
\text { COLLABORATION }\end{array}$ & $\begin{array}{lr}\text { JOINT } & \text { VENTURES } \\
\text { AND MERGERS, } \\
\text { MAXIMIZING } \\
\text { COMPANY VALUE } \\
\text { BY INCREASING } \\
\text { EQUITY } \\
\end{array}$ & $\begin{array}{l}\text { FINANCIAL AND } \\
\text { INDUSTRIAL GROUP, } \\
\text { PUBLIC-PRIVATE } \\
\text { PARTNERSHIP, CONTINUOUS } \\
\text { VALUE ADDITION }\end{array}$ \\
\hline
\end{tabular}

Stimulating the innovative development of lagging regions, ensuring the uniformity of the territorial distribution of innovative potential is a prerequisite for the maturity of the innovative environment of individual regions and the country as a whole. The inevitability of digital transformation contributes to the active advancement of digital ecosystems and is the key to the success of the innovative development of the national economy.

\section{REFERENCES}

[1] J. Schumpeter, Theory of Economic Development, Moscow: Progress, 1982.

[2] P. Drucker, Business and Innovation, Moscow: Williams Publishing House, 2007.

[3] L. S. Blyakhman, Economics, management organization and planning of scientific and technological progress, Moscow: Higher School, 1991.

[4] F. Nixon, Innovation Management, Moscow: Economics, 1997.

[5] A. I. Prigozhin, Innovations: incentives and obstacles: (social problems of innovatics), Moscow: Politizdat, 1989.

[6] B. Santo,'Innovation as a Means of Economic Development, Moscow: Progress, 1990.

[7] I.V. Safronov, "Concepts of "innovation" and "innovative activity" essence and content", $2008 . \quad$ URL: http://vernadsky.tstu.ru/pdf/2008/04g/32g 14.pdf. Iaccessed 07.11.2020).

[8] R.A. Fathutdinov, Innovation Management, St. Petersburg: Peter, 2010.

[9] A.V. Surin, O. P. Molchanova, Innovation Management, Moscow: INFRA-M, 2008

[10] S. P. Kurdyumov, V. Yu. Katasonov, V.V. Maslennikov, V.V. Ivanov, "Introduction to the Theory of Digital Economy", 2018 URL: $\quad$ http://spkurdyumov.ru/uploads/2018/12/vvedenie-v-teoriyucifrovoj-ekonomiki.pdf) (accessed 10.11.2020).

[11] M.A. Averyanov, S.N. Yevtushenko, E.Yu. Kochetova, "Digital Society: New Challenges", Economic Strategies, 2016, vol.7. URL: http://spkurdyumov.ru/uploads/2016/12/cifrovoe-obshhestvo-novyevyzovy.pdf

[12] V.V. Ivanov, G.G. Malinetsky, Digital economy: myths, reality, prospects, Moscow: 2017
[13] T.V. Poltevoa, N.N. Bykova, "Modern state of the digital financial technology market in Russia", Karelian Scientific Journal, 2017, vol. 4. URL: https://cyberleninka.ru/article/n/sovremennoe-sostoyanie-rynkatsifrovyh-finansovyh-tehnologiy-v-rossii (accessed 10.11.2020).

[14] I.L. Avdeeva, T.A. Golovina, L.V. Parakhina, "Development of digital technologies in economics and management: Russian and foreign experience", Management issues, 2017, vol. 6. URL: vestnik.uapa.ru/ru/issue/2017/06/06/ (accessed 10.09.2020).

[15] D. Tapscott, The Digital Economy: Promise and Peril In The Age of Networked Intelligence, McGraw-Hill: 1995.

[16] K. Schwab, Fourth Industrial Revolution, Moscow: Publishing House "E," 2017.

[17] P. Lindholm, S. Klesova, "Economic development of territories through innovation, science and technology", Innovations, 2002, vol. 10.

[18] M. B. Jensen, B. Johnson, E. Lorenz, B. A. Lundvall, "Forms of knowledge and modes of innovation",Research policy, Amsterdam, 2007, vol. 36, pp. 680-693.

[19] S. V. Basov, I. B. Ilyukhin, National "Innovation Systems: Concept Formation", National interests: priorities and security, 2009, vol. 8, pp $57-62$

[20] A. A. Adzhiev, "On the issue of assessing the degree of maturity of the innovative environment of the region", Management sciences in the modern world, 2018, vol.1. URL: https://elibrary.ru/download/elibrary 35112687 68092629.pdf (accessed 08.09.2020).

[21] D.A. Nikolaev, "Clarification of life cycle stages of regional innovation clusters, National interests: priorities and security", 2019, vol.2, pp.343-358. DOI: https://doi.org/10.24891/ni.15.2.343.

[22] F. Demir, "A Strategic Management Maturity Model for Innovation", Technology Innovation Management Review, 2018, vol. 11. URL: https://timreview.ca/sites/default/files/ article_PDF/Demir_TIMReview_November2018.pdf. (accessed 10.11.2020), DOI: http://doi.org/10.22215/timreview/1196.

[23] J. Nick, P. Atkin, "A step in the right direction-improving organization PM maturity", Washington, DC, 2010.

[24] T. Kolmykova, E. Merzlyakova, B. Preobrazhensky, N. Serebryakova, "Problems of investment support for innovative development", Proceedings of the 33rd International Business Information Management Association Conference, IBIMA 2019: Education Excellence and Innovation Management through Vision, 2020, 2019, pp. 2199-2204.

[25] T.S. Kolmykova, O.V. Ostimuk, A.S. Obukhova, "Role of Institutional Investors in the Resource Provision of the Region's Economic Growth", Journal of Advanced Research in Law and Economics, 2017, Volume VIII., Issue 8(30), pp. 2439-2448. DOI: https://doi.org/10.14505/jarle.v8.8(30).14.

[26] N. Kazarenkova, A. Obukhova, T. Svetovtseva, O. Aseev, "Transformation of the russian banking system in digital economy", Proceedings of the 33rd International Business Information Management Association Conference, IBIMA 2019: Education Excellence and Innovation Management through Vision 2020, 2019, pp. 1456-1461. 